\title{
走行速度を考慮した降雨強度推定手法の提案 A SUGGESTION FOR A RAINFALL ESTIMATION METHOD TAKING THE VEHICLE SPEED INTO CONSIDERATION
}

\author{
東俊孝 1 ・矢神卓也 $2 \cdot$ 中北英一 $3 \cdot$ 古賀光彦 4 \\ Toshitaka AZUMA, Takuya YAGAMI, Eiichi NAKAKITA and Mitsuhiko KOGA \\ 1正会員 工修 （一財）道路交通情報通信システムセンター（テ104-0031 東京都中央区京橋2-5-7） \\ 2正会員 工修 株式会社建設技術研究所（广103-8430 東京都中央区日本橋浜町3-21-1） \\ 3正会員 工博 京都大学教授 防災研究所（广611-0011 京都府宇治市五厅庄5） \\ 4 非会員 専務理事 （一財）道路交通情報通信システムセンター（テ104-0031 東京都中央区京橋2-5-7）
}

\begin{abstract}
Next-generation VICS services that provide useful information to drivers are scheduled for launch in April 2015, following FM multiplex broadcasting band extension. One of the new services includes roadway hazard warning, especially under heavy rainfall conditions, which provides alerts through automatically converting raster rainfall data to vector data and superimposing it onto a digital map displayed on the car navigation display. This research is the first to take up "rainfall intensity experienced by a running vehicle" while previous researches have not explicitly did. In addition, we make a unique step toward the promotion of drivers' prior actions for avoidance, utilizing "rainfall intensity experienced by a running vehicle". In this research, a threshold for XRAIN rainfall information is defined at $50 \mathrm{~mm} / \mathrm{h}$, and a rainfall estimation method using XRAIN rainfall information is proposed, taking the vehicle speed into consideration.
\end{abstract}

Key Words : Next-generation VICS services, XRAIN Rainfall Information, Rainfall estimation

\section{1. はじめに}

\section{(1) 背景}

近年，都市域を中心とした局地的豪雨（いわゆるゲリ ラ豪雨) や集中豪雨の発生頻度が増加しており，道路冠 水等の被害も多数報告されている．国土交通省では，よ り詳細な雨量情報の提供を目的としてXRAINを構築して おり，平成25年度からは（一財）河川情報センターを通 じてXRAIN合成雨量情報を有料配信している．XRAIN合成 雨量情報は, 従来のCバンドレーダ雨量と比較して, 時 間的にも空間的にも高分解能となり, 精度の高い雨量情 報を提供可能なため, 風水害軽減のための強力なツール として期待されている.

一方, 我が国では, VICS (Vehicle Information and Communication System）と呼ばれる道路交通情報通信シ ステムが知られている1).VICSは，加工済みの道路交通 情報（渋滞情報，特定区間の旅行時間情報，規制情報等） をVICS 対応の車載機に電波ビーコン（radio wave beacon), 光ビーコン（infrared beacon）及びFM多重放 送（FM multiplex broadcasting）等のメディアを介してリ アルタイムで提供するシステムである.

VICSセンターでは，平成27年度からFM多重放送の帯 域拡張に伴い，ドライバーへ有益な情報を配信する次世
代VICSサービスを開始予定である，次世代VICSサービ スの1つとして，XRAIN合成雨量情報を自動でポリゴン化 し，車載機の電子地図上へ重畳することにより，ドライ バーに対して安全性を損なわずに注意喚起するサービス を想定している. XRAIN合成雨量情報は $250 \mathrm{~m}$ メッシュで 与えられ，FM多重放送の東京放送局内だけでも約 200KB/minとデータ容量が非常に大きく, 限られた伝送 帯域で車両へ直接送信することは, 極めて困難である. 多降水地区を車載機へ提供するためには，情報量削減と 直感的な視認性向上が大きな課題となっていた，そこで， 多降水地区をポリゴン生成し，頂点座標のみを伝送する ことで，情報量を $10 \%$ 以下に低減可能だが，ポリゴン生 成のための適切な降雨強度の閾值を設定する必要があっ た。なお，従来研究では，「運転者が感じる降雨強度 (走行時降雨強度と定義)」を明示的に取り上げていな いのに対して, 本研究では新たに着目した.ささらに,

「走行時降雨強度」により, 速度低下や走行危険性のあ る多降水地区を注意喚起情報としてサービス提供し, 運 転者の事前回避行動に結びつけようとする試みが新しい. (2) 目的

本研究では, 突発的な豪雨による走行車両のリスクを 事前回避するために，XRAIN合成雨量情報の閾值及び 設定根拠を整理した上で, 風速, 雨滴落下速度及びフロ 
ントガラス傾斜角に加えて, 走行速度を考慮した降雨強 度推定手法を新たに提案する。さらに，XRAIN合成雨 量情報と走行時降雨強度の関係性を整理した上で, 理論 式の妥当性を確認し，注意喚起に最適なXRAIN合成雨 量情報の閾值を設定する.

\section{2. 既往の研究整理}

本章では，降雨強度の閾値を設定するために，時間雨 量と走行車両の関係や道路冠水一の影響に関連寸る既往 の文献を調查・整理する，さらに，諸外国での取り組み 状況も考慮し, 本研究の位置付けと意義について述べる. （1）集中豪雨時の交通行動に関する研究

時間雨量に対する帰宅行動，走行速度及び道路冠水に 関する研究は, 主として藤田らの研究によって整理され ている. 以下，テーマ毎に概要を整理する.

\section{a）時間雨量と帰宅行動の関係}

雨量情報を入手した際の自動車帰宅行動に関する調査 2)では，一般市民にとって，帰宅を遅らせる目安は「時 間雨量 $30 \mathrm{~mm}$ 時間雨量 $50 \mathrm{~mm} 」$ が多いと指摘されてい る. さらに，集中豪雨時の交通行動に関する調查では，

「時間雨量 $60 \mathrm{~mm}$ 」以上の情報提供がされた場合に，一 時退避・引き返し等の行動が顕著になるとの知見が得ら れている.

\section{b）時間雨量と走行速度の関係}

東海豪雨時の広域的道路交通解析了)では，タクシード ライバーに対して豪雨当時の走行に関するアンケート調 査を実施しており，「時間雨量 $50 \mathrm{~mm} 」$ 以上の場合に走 行速度の顕著な低下が見受けられ，豪雨のピーク時（時 間雨量 $90 \mathrm{~mm}$ 以上) では走行速度は $5 \mathrm{~km} / \mathrm{h}$ 程度となり, 激 しい渋滞となることが示されている. 走行速度は走行距 離と所要時間の関係より算定されている.

\section{（2）集中豪雨時の交通状況に関する研究}

JARTIC田波らは4)，愛知県警から提供を受けた5分更 新の橴滞情報と交通量データを活用して，名古屋市内に おける集中豪雨時の渋滞状況や交通量の変化状況を把握 している. 集中豪雨時において安全運転のための速度低 下は許容できるが，渋滞緩和策として速度が回復傾向を 示している路線ネットワーク等へ誘導・分散していく必 要性があるという結論を得ている.

\section{（3）降雨の影響を考慮した速度推定に関する研究}

東京大学の洪らは5), 多車線高速道路の単路部におけ る非渋滞流を対象に, 道路線形条件, 交通量及び大型車 混入率といった交通条件，降雨量の有無を反映した統合 型速度推定モデルを構築している．降雨量の速度低下 の影響は線形的でなく, 非降雨時から降雨時に変化する 際（降雨量 $0 \mathrm{~mm}$ から $1 \mathrm{~mm}$ へ変化）の速度低下量が最 も大きいことが指摘されている.

\section{（4）下水道施設の計画雨水量}

社団法人日本下水道協会では下水道施設計画と設計指
針について解説しており ${ }^{6}$, 下水道施設の観点から計画 雨水量として雨水流出ピーク量を算出する場合は, 最大 計画雨水流出量を用いている. なお，下水道施設計画は 5〜10年確率であることから，概ね「時間雨量 $50 \mathrm{~mm}$ に 対応した市町村が多いことが示されている. 名古屋市内 の調查 ${ }^{7}$ では,「時間雨量 $50 \mathrm{~mm}$ 以上になると道路冠水 が発生する可能性が高いと示されている.

（5）時間雨量と自動車運転の関係

気象庁では, 時間雨量と自動車運転との関係 ${ }^{8}$ につい て詳細に記載しており，以下の指針が示されている

・時間雨量 $20 \mathrm{~mm}$ 以上〜時間雨量 $30 \mathrm{~mm}$ 未満では, ワイ パーを速くしても見づらい状況にある.

・時間雨量 $30 \mathrm{~mm}$ 以上〜時間雨量 $50 \mathrm{~mm}$ 未満では, 高速 走行時，車輪と路面の間に水膜が生じブレーキが効か なくなる（ハイドロプレーニング現象）。

・時間雨量 $50 \mathrm{~mm}$ 以上の場合は，車の運転は危険である。 なお，本資料は，時間雨量と自動車運転の危険性を把 握する上で大変貴重であるが, 気象庁関係者へのヒアリ ングを通じても根拠となる情報を確認できなかった。

\section{（6）諸外国での学術的な取り組み}

降雨と走行車両に関係する学術的な取り組みに関して 米国土木学会の出版物を中心に調査した結果, 慣性計測 装置と高精細3Dデータに基づいて道路舗装のハイドロ プレーニング現象によるリスクを評価する研究9)，事故 予測モデルにおける降雨の影響の重要性を指摘する研究 10)，降雨による自動車の挙動について経路選択の変更や 旅行時間の遅延を指摘している研究 ${ }^{11)}$ が散見する. しか しながら，走行速度を考慮した1分毎の降雨強度推定や 公的な道路交通情報の一部として多降水地区を提供して いくといった観点の研究は見受けられない.

\section{（7）本研究の位置付けと意義}

既往の文献を整理した結果，車両走行時に危険と判断 される目安は, 1 時間雨量 $50 \mathrm{~mm}$ 発生時といえる. また, 1 時間雨量50mm以上が発生した場合は, 一般道路におけ る道路冠水の発生確率が高まる傾向にある.

一方, 本研究では「走行時降雨強度」が運転者の危険 度に対する真の指標になるという発想から着手している. なお，諸外国での取り組み状況を調查する過程において， 我が国以外にVICSのような公的機関が収集した道路交 通情報をリアルタイムにドライバーへ放送するシステム 自体が存在しないことが判った．XRAINのような降雨 強度を高頻度かつ高精細に配信できる最新鋭の公的シス テムとの組み合わせを考慮すると，本研究は諸外国を含 めても初めての取り組みとして位置付けられる. また, 走行中のドライバーが感じる降雨量の推定という観点の 研究は見受けられず, 車両走行時の降雨強度の考え方に 関する学術的な知見も体系的に整理されていない。

以上の事実から, 本研究は新たな領域に対する取り組 みであり, 車両走行に影響を与える降雨現象を解明して いく上でも，非常に意義があるといえる. 


\section{3. アプローチ}

\section{（1）車両走行時の降雨強度の考え方}

本研究では，図-1に示寸ように，車両走行時は停止時 に比べて車速，風速，雨滴落下速度及びフロントガラス 傾斜角に応じてドライバーが感じる降雨量に変化が生じ るという仮説を設定した上で，走行時降雨強度の推定式 を新たに提案する。なお，「XRAIN合成雨量情報」は 「停車時降雨強度」と定義する，具体的な内容について は，後述する.
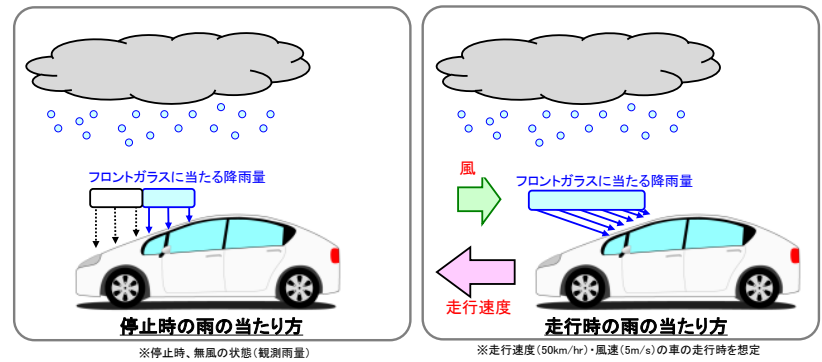

図-1 停止時と走行時の降雨の当たり方

\section{（2）走行時降雨強度の推定方法}

車両の走行時は，停止時の降雨量に比心，多くの降雨 量がフロントガラスに当たると考えられる．車両走行時 の雨滴の当たり方を図-2に示す.

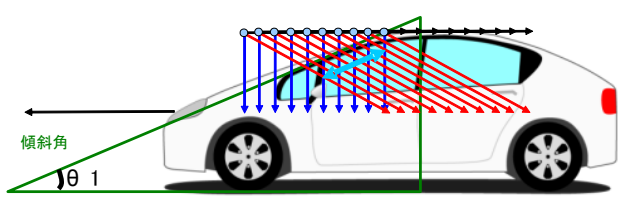

図-2＼cjkstart車両走行時の雨滴の当たり方（赤色矢印）

なお，フロントガラスに当たる特定の雨滴に着目した 場合，車両走行時の各速度の合成值は，図-3に示寸関係 から算出できる.

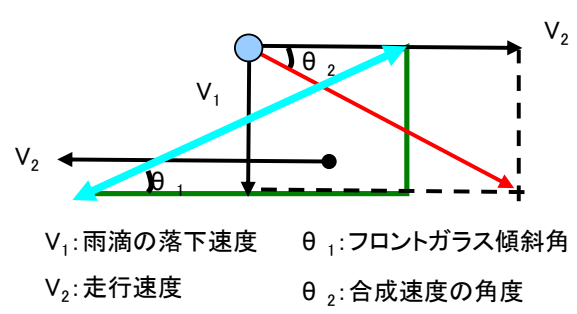

図-3 車両走行時の各速度の合成值（赤色矢印）

以上の仮定により，本研究では，図-3及び図-4に示寸 関係から，車両走行時と停止時のフロントガラスに衝突 する雨滴の存在範囲を基に走行時降雨強度を推定する. 具体的には，式(1)に示すように，単位時間あたりの雨滴 落下距離Hと停止時のフロントガラスに衝突する雨滴存 在範囲 $\mathrm{L}$ ，及びフロントガラスの傾斜角 $\theta_{1}$ の関係を定義 寸る. 式(2)において, 雨滴の落下速度 $\mathrm{V}_{1}$ と車両走行速
度 $\mathrm{V}_{2}$ から合成速度の角度 $\theta_{2}$ を求める. 一方で, この関 係は，単位時間あたりの雨滴落下距離Hと車両走行時に 増加したフロントガラスに衝突する雨滴存在範囲L'との 関係に等しい. よって, 式(1)〜(2)より, 車両走行時の フロントガラスに衝突する雨滴の存在範囲 $\mathrm{L}+\mathrm{L}$ ' と停 止時のフロントガラスに衝突する雨滴の存在範囲 $\mathrm{L} の$ 比 は式(3)で示される. 走行時降雨強度は停車時降雨強度に 比べて「1 $+\tan \theta_{1} \times \mathrm{V}_{2} / \mathrm{V}_{1}$ 倍」に増幅されると解釈で きる.

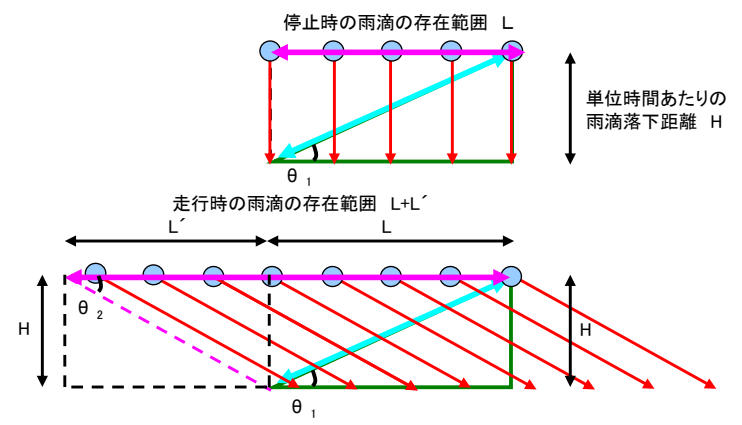

図-4＼cjkstart車両走行時の合成速度と雨滴の存在範囲の関係

$\tan \theta_{1}=\frac{\mathrm{H}}{\mathrm{L}} \quad \therefore \mathrm{H}=\mathrm{L} \times \tan \theta_{1}$

$\tan \theta_{2}=\frac{\mathrm{V}_{1}}{\mathrm{~V}_{2}}=\frac{\mathrm{H}}{\mathrm{L}^{\prime}}$

式(1)〜(2)より,

$\mathrm{L}^{\prime}=\frac{\mathrm{H}}{\tan \theta_{2}}=\mathrm{H} \times \frac{\mathrm{V}_{2}}{\mathrm{~V}_{1}}=\mathrm{L} \times \tan \theta_{1} \times \frac{\mathrm{V}_{2}}{\mathrm{~V}_{1}}$

$\frac{\mathrm{L}+\mathrm{L}^{\prime}}{\mathrm{L}}=\frac{\mathrm{L}+\mathrm{L} \times \tan \theta_{1} \times \frac{\mathrm{V}_{2}}{\mathrm{~V}_{1}}}{\mathrm{~L}}=1+\tan \theta_{1} \times \frac{\mathrm{V}_{2}}{\mathrm{~V}_{1}}$

\section{（3）フロントガラス傾斜角}

一般的な普通車のフロントガラス傾斜角は，20～30度 程度である。本研究では 図-5に示寸ように，フロント ガラス傾斜角 $\theta_{1}$ を25度に設定した。

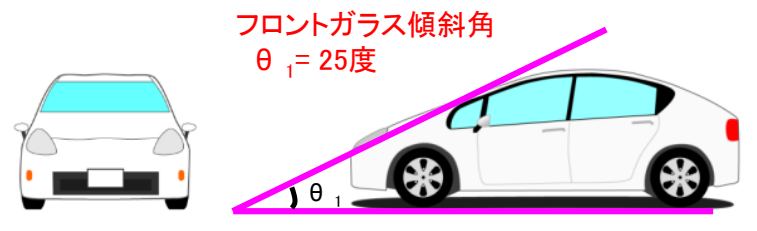

図-5 フロントガラス傾斜角

\section{（4）雨滴の落下速度の設定}

a）降雨強度と雨滴粒径分布の中央値の関係

降雨強度毎の雨滴粒径分布の中央值 $\mathrm{D}_{0}(\mathrm{~mm})$ は, 統 計的手法であるMarshall and Palmer分布より，パラメー タ $\Lambda(1 / \mathrm{mm})$ 及び降雨強度 $\mathrm{R}(\mathrm{mm} / \mathrm{h})$ とすると, 式(4)で 算出されることが知られている。本研究では，後述する 実証実験で利用寸る降雨強度と雨滴粒径分布の中央值の 関係を表-1に示す。

$\mathrm{D}_{0}=\frac{3.67}{\Lambda}=\frac{3.67}{4.1 \mathrm{R}^{-0.21}}$ 
表-1 降雨強度と雨滴粒径分布の中央値の関係

\begin{tabular}{ccc}
\hline Case & $\begin{array}{c}\text { 降雨強度 } \mathrm{R} \\
(\mathrm{mm} / \mathrm{h})\end{array}$ & $\begin{array}{c}\text { 雨滴粒径分布の } \\
\text { 中央值 } \mathrm{D}_{0}(\mathrm{~mm})\end{array}$ \\
\hline \hline 1 & 30 & 1.83 \\
\hline 2 & 50 & 2.04 \\
\hline 3 & 100 & 2.35 \\
\hline 4 & 150 & 2.56 \\
\hline
\end{tabular}

\section{b）降雨強度と雨滴の落下速度の関係}

大気中での降水粒子の落下速度 $\mathrm{V}_{1}(\mathrm{~m} / \mathrm{s})$ には，多く の式が提案されている. 本研究ではAtlas et al. ${ }^{12)} に$ 従い, 式(5)を用いて雨滴粒径分布の中央值毎に算出した. なお, 後述する降雨実験で利用する降雨強度と雨滴の落下速度 の関係を表-2に示す。

$\mathrm{V}_{1}=9.65-10.3 \mathrm{e}^{-0.6 D_{0}}$

\section{表-2 降雨強度と雨滴の落下速度の関係}

\begin{tabular}{cccc}
\hline Case & $\begin{array}{c}\text { 降雨強度 } \\
\mathrm{R}(\mathrm{mm} / \mathrm{h})\end{array}$ & $\begin{array}{c}\text { 雨滴粒形分布の } \\
\text { 中央值 } \mathrm{D}_{0}(\mathrm{~mm})\end{array}$ & $\begin{array}{c}\text { 雨滴の落下速度 } \\
\mathrm{V}_{1}(\mathrm{~km} / \mathrm{h})\end{array}$ \\
\hline \hline 1 & 30 & 1.83 & 22.4 \\
\hline 2 & 50 & 2.04 & 23.8 \\
\hline 4 & 100 & 2.35 & 25.7 \\
\hline
\end{tabular}

\section{（5）走行速度と風速の設定}

交通規制基潐 ${ }^{13}$ により，一般道路における基準速度は， 40 60km/hである. 本研究では, 車両の走行速度 $\mathrm{V}_{2}$ を 一般道路の平均基準速度である $50 \mathrm{~km} / \mathrm{h}$ に設定した。 なお, 高強度の降雨時には風が吹くことが知られており，走行 方向に対して向い風 $\mathrm{V}_{3}$ が発生している場合が最も影響 が大きく, 雨滴の水平方向の速度成分が $\mathrm{V}_{2}+\mathrm{V}_{3}(\mathrm{~m} / \mathrm{s})$ に増大される，そのため，向い風を考慮した際の各速度 の合成值は，図-6に示寸赤色実線矢印となる.

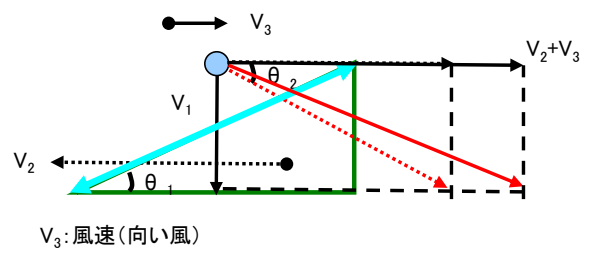

図-6＼cjkstart向い風を考慮した際の各速度の合成值

また，気象庁統計情報を利用して過去の東京都内にお ける豪雨時の記録（2010年7月5日，2013年7月23日， 2013年7月 27 日の 3 事例）を整理した結果， 1 時間雨量 $50 \mathrm{~mm}$ 以上の降雨時には，最大瞬間風速 $5.0 \sim 7.5 \mathrm{~m} / \mathrm{s}$ 程度 が発生していることが判った．また，豪雨時の風に関す る文献を調査した結果 ${ }^{14}$ ，積乱雲を構成する対流セルに ついて，最盛期では下部分に下降流があり，1995年8月 豪雨時（熊谷）の事例では1時間雨量50mm発生時に地上
風速 $5.0 \mathrm{~m} / \mathrm{s}$ 程度の強風が発生することを確認できた。 上 記の調査結果より, 本研究では, 豪雨時の風速 $\mathrm{V}_{3}$ （向 い風）として， $5.0 \mathrm{~m} / \mathrm{s} （ 18 \mathrm{~km} / \mathrm{h} ）$ を設定した.

\section{（6）車両走行時の降雨強度の倍率}

本研究では，前述した各パラメータの設定值に基づき， 車両走行時の降雨強度の倍率を式(6)に示寸

$$
\begin{aligned}
\frac{\mathrm{L}+\mathrm{L}^{\prime}}{\mathrm{L}} & =1+\tan \theta_{1} \times \frac{\mathrm{V}_{2}+\mathrm{V}_{3}}{\mathrm{~V}_{1}} \\
& =1+\tan (25 \text { deg. }) \times \frac{68}{\mathrm{~V}_{1}}
\end{aligned}
$$

\section{4. 実証実験}

\section{（1）落下速度の妥当性評価}

理論式による降雨強度毎の落下速度の設定について， その妥当性を評価するため，2012年8月14日（宇治豪雨） の実降雨時の2次元ディスドロメータデータ（2DVD データ）と比較した. 図-7に示すように, 縦軸を落下速 度，横軸を雨滴粒径として2DVDデータを整理したとこ ろ, 式(5)から得られる理論值との整合性があることを確 認できた.

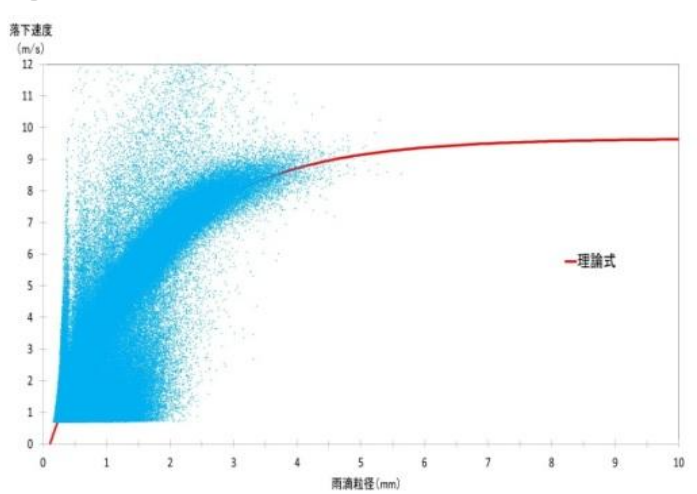

図-7＼cjkstart理論値と2DVDデータの比較（2012/8/14 3:00-4:00）

\section{（2）車両走行時の降雨強度の試算}

本研究では, 式(6)から得られる走行時の降雨強度 ( $\mathrm{mm} / \mathrm{h})$ を, フロントガラス傾斜角 (25度) , 走行速 度 $(50 \mathrm{~km} / \mathrm{h})$, 風速（向い風 $18 \mathrm{~km} / \mathrm{h} ）$ を考慮して, 表-3 のように試算した，試算した範囲内では，停車時降雨強 度によらず約 2 倍の走行時降雨強度になると解釈できる.

\section{表-3 車両走行時の降雨強度毎の試算一覧}

\begin{tabular}{cccc}
\hline Case & $\begin{array}{c}\text { 停車時の } \\
\text { 降雨強度 }(\mathrm{mm} / \mathrm{h})\end{array}$ & $\begin{array}{c}\text { 雨滴の落下速度 } \\
\mathrm{V}_{1}(\mathrm{~km} / \mathrm{h})\end{array}$ & $\begin{array}{c}\text { 走行時の } \\
\text { 降雨強度 }(\mathrm{mm} / \mathrm{h})\end{array}$ \\
\hline \hline 1 & 30 & 22.4 & 72 \\
\hline 2 & 50 & 23.8 & 117 \\
\hline 3 & 100 & 25.7 & 223 \\
\hline 4 & 150 & 26.8 & 327 \\
\hline
\end{tabular}

\section{（3）車両走行を想定した降雨実験}

本研究では, 走行速度を考量した降雨強度推定手法の 妥当性について，人工降雨により評価した．フロントガ 
ラスに衝突する雨粒が拡散することにより前方視認性が 低下寸る仮説を設定した上で, 屋内実験において停車時 降雨強度から走行時降雨強度の影響を推定した。 なお， 車両走行時における車体に沿う流れによる粒径分布の変 形可能性及び自然界の雨滴粒径分布の影響については今 後の課題とした. また，視認性の実験結果に関寸る考察 については，気象庁の「風之雨」の資料内にある「雨の 強さと降り方」に関寸る記載内容及び京都大学防災研究 所中北教授の照査結果から総合的に判断し, 記載した.

\section{a) 実験目的}

自動車運転が危険とされる降雨強度の閾值を設定寸る ために，ドライバー視点での前方視認性を確認した.

\section{b) 実験施設}

京都大学防災研究所宇治川オープンラボラトリー内の 雨水流出実験装置を使用した.

\section{c）実験条件}

本実験の検討ケースを表-4に示す。 表-4 実験条件

\begin{tabular}{cccc}
\hline Case & $\begin{array}{c}\text { 停車時の } \\
\text { 降雨強度 }(\mathrm{mm} / \mathrm{h})\end{array}$ & $\begin{array}{c}\text { 走行時の } \\
\text { 降雨強度 }(\mathrm{mm} / \mathrm{h})\end{array}$ & $\begin{array}{c}\text { 設定流量 } \\
(\mathrm{l} / \mathrm{min})\end{array}$ \\
\hline \hline 1 & 30 & 72 & 113 \\
\hline 2 & 50 & 117 & 183 \\
\hline 3 & 100 & 223 & 349 \\
\hline 4 & 150 & 327 & 512 \\
\hline
\end{tabular}

※実験施設の降雨強度と設定流量の関係

設定流量 $(1 / \mathrm{min})=94 / 60 \times$ 走行時の降雨強度 $(\mathrm{mm} / \mathrm{h})$

\section{d）実験方法}

本実験では，最も前方視認性が悪くなる降雨時の夜間 走行を想定し，図-8に示すような配置により，以下の 3 項目を実施した.

・車間距離は $50 \mathrm{~km} / \mathrm{h}$ 走行の1秒に相当する $15 \mathrm{~m}$ 設定する.

・後方車のライトはONの状態とする.

・前方車のブレーキランプの見え方を確認する.

\section{e）記録方法}

本実験では，以下の2項目に留意して記録した。

・後方車の運転席より, ビデオカメラによる動画を撮影 する.

・ワイパーの稼働状況，フロントガラスの雨滴状況及び 前方車のブレーキランプの見え方を確認する.

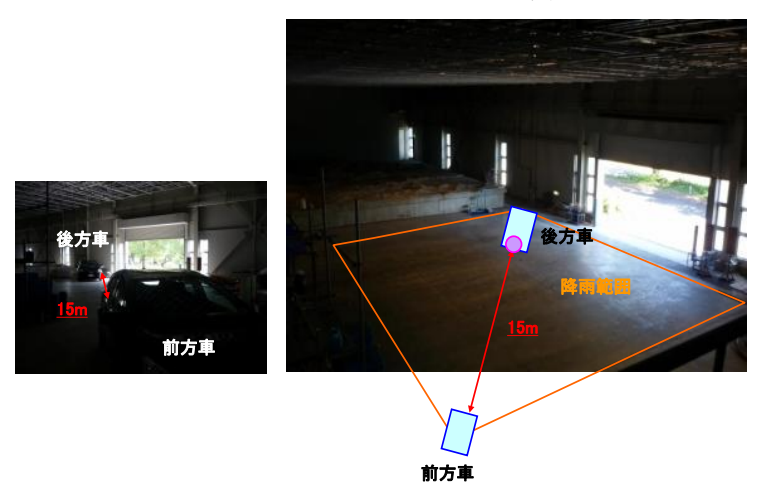

図-8＼cjkstart実験時の車両配置

\section{（4）実験結果}

本実験では，降雨強度 $50 \mathrm{~mm} / \mathrm{h}$ 以上のように高強度の 降雨が発生した場合，ワイパーを最速で稼働させても視 認性が悪くなる傾向が見受けられた（表-5）。前方視認 性の比較結果を図-9に示す，なお，本実験で得られた視 認性に関する知見は以下の2点である.

・XRAIN合成雨量情報（停車時降雨強度）が50mm/hを 示寸場合, 走行時降雨強度は $100 \mathrm{~mm} / \mathrm{h}$ 超となり, 前方 視認が悪くなり，減速が必要となる

・XRAIN合成雨量情報（停車時降雨強度）が $100 \mathrm{~mm} / \mathrm{h}$ 超 を示寸場合, 走行時降雨強度は $200 \mathrm{~mm} / \mathrm{h}$ 超となり, 徐 行運転や車両停止といった運転困難又は運転不可とな る状況が発生する

\section{表 -5 視認性の実験結果}

\begin{tabular}{cccc}
\hline Case & $\begin{array}{c}\text { 停車時の } \\
\text { 降雨強度 }(\mathrm{mm} / \mathrm{h})\end{array}$ & $\begin{array}{c}\text { 走行時の } \\
\text { 降雨強度 }(\mathrm{mm} / \mathrm{h})\end{array}$ & 考察 \\
\hline \hline 1 & 30 & 72 & - \\
\hline 2 & 50 & 117 & 減速必要 \\
\hline 3 & 100 & 223 & 運転困難 \\
\hline 4 & 150 & 327 & 運転不可 \\
\hline
\end{tabular}

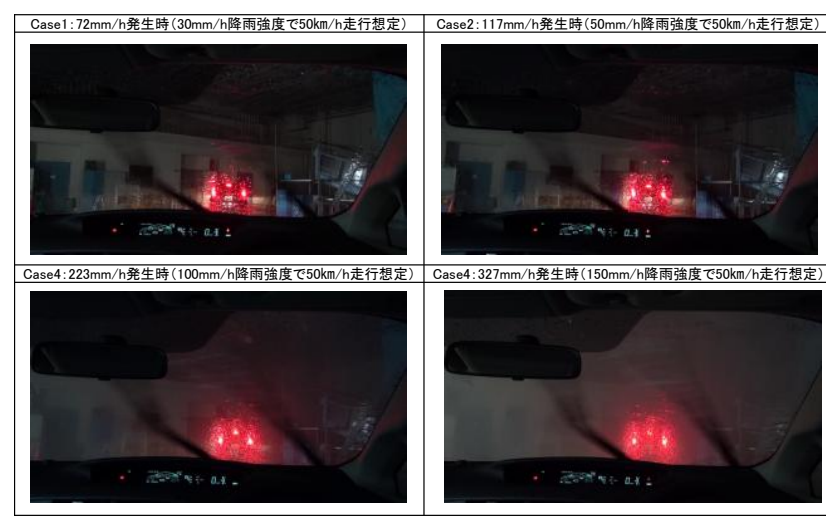

図-9＼cjkstart前方視認性の比較結果

\section{（5）短時間降雨強度の特性把握}

本研究では，XRAINで配信される現時刻雨量（1分毎 の合成雨量）の利用を前提としているため, 配信雨量 データが表現している空間的及び時間的な降雨強度の特 性を整理した。

\section{a）XRAIN合成雨量情報の空間特性}

近畿地方の宇治周辺で発生した前線性の豪雨（2012年 8月14日）を対象として，XRAIN合成雨量情報の時系 列変化を整理した。 その結果，図-10に示すように，車 両走行時に減速対応が必要となる降雨強度 $50 \mathrm{~mm} / \mathrm{h}$ 以上 の多降水地区の中には，運転自体が困難となる $100 \mathrm{~mm} / \mathrm{h}$ 以上の雨域が含まれていることを視覚的に確認できた. 降雨強度 $50 \mathrm{~mm} / \mathrm{h}$ を閾值とすることにより, 注意喚起を 含めた領域を指定できるため，安全側の情報提供が可能 といえる. 


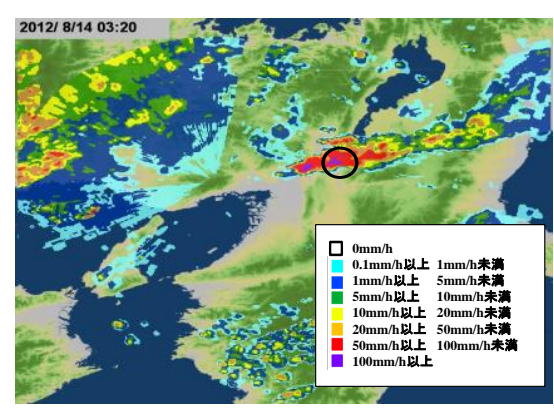

図-10 XRAIN合成雨量情報の可視化例（2012/8/14 3:20） b）XRAIN合成雨量情報の時間特性

前述した前線性の豪雨を対象として，地上に設置され た2DVDデータと同地点のXRAIN合成雨量情報を，1分 毎の降雨強度で比較した（図-11）。その結果，XRAIN 合成雨量情報は，地上の2DVDデータに比べて，降雨強 度 $100 \mathrm{~mm} / \mathrm{h}$ 以上の非常に強い降雨時に過小に観測される 傾向が見受けられるものの，全体的には同様の傾向を示 すことが判った. また，降雨強度 $50 \mathrm{~mm} / \mathrm{h}$ 発生の数分後に, 降雨強度 $100 \mathrm{~mm} / \mathrm{h}$ 以上の激しい降雨の発生確率が高まる ことが示唆された。

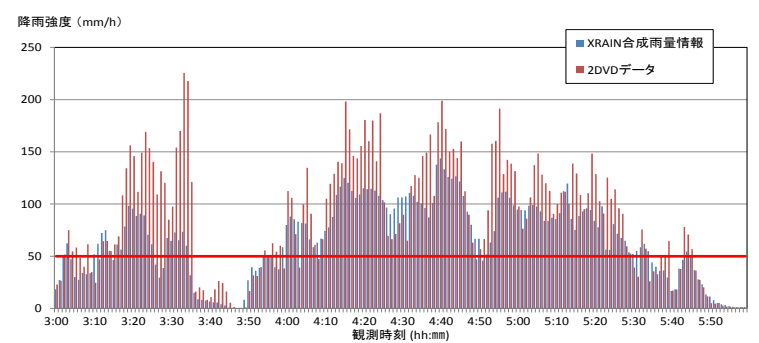

図-11 1分毎の降雨強度の比較 (2012/8/14 3:00-6:00)

\section{5. まとめ}

本研究では，車両走行時の豪雨による危険回避を目標 として, 車載機上での直感的理解とデータ容量削減のた めに，降雨強度の閾值設定とその根拠を整理した。 さら に, 走行速度を考慮した降雨強度推定手法を提案し, 屋 内施設による降雨実験をした。 実証実験の結果, 向い風 $5 \mathrm{~m} / \mathrm{s}$ を考慮して一般道路の平均基準速度 $50 \mathrm{~km} / \mathrm{h}$ で走行し た場合，普通車のフロントガラス上では約 2 倍の降雨強 度になることが判った. この条件下で走行するドライ バーは，XRAIN合成雨量情報が降雨強度 $50 \mathrm{~mm} / \mathrm{h}$ を示す 場合, 走行時降雨強度 $100 \mathrm{~mm} / \mathrm{h}$ 超を感じるため, 視界不 良による速度低下や徐行運転を寸る可能性がある。なお， 降雨強度 $50 \mathrm{~mm} / \mathrm{h}$ 以上の多降水地区では, 走行時降雨強 度 $200 \mathrm{~mm} / \mathrm{h}$ 以上（XRAIN合成雨量情報 $100 \mathrm{~mm} / \mathrm{h}$ 以上）の 走行自体が危険なエリアを包括できるため, 注意喚起情 報として適切といえる.

今後の展開としては, XRAIN合成雨量情報以外の情 報源の利用や雨滴粒径分布の影響を考慮した高度化手法 の検討を継続していく予定である.

謝辞 : 本研究で利用したXRAIN合成雨量情報は，国土交
通省水管理・国土保全局より貸与して頂いた．2DVDデー 夕は，国土交通省近畿地方整備局から貸与して頂いた。 実証実験では京都大学防災研究所の藤原清司氏をはじめ, (株) 建設技術研究所の荒木孝之主任など多くの関係者に ご協力を頂いた．また，京都大学防災研究所の山口弘誠 特定助教には2DVDデータ解析に際して貴重なご意見を頂 いた.ここに記して感謝の意を表す。

\section{参考文献}

1) 財団法人道路交通情報通信システムセンター: 交通および 関連情報の表現方法, 特許第3842536号, 2006-11-08.

2) 坂本淳, 藤田素弘, 鈴木弘司, 山本幸司 : 集中豪雨下にお ける自動車帰宅交通行動と情報提供に関する研究，土木計 画学研究・論文集, Vol. 24, No.4, PP. 861-868, 2007.

3) 藤田素弘, 伊藤大介, 三田村純: 集中豪雨時の広域的道路交 通解析と帰宅行動意識および対策検討, 土木計画学研究 講演集 No.27(CD-ROM), 2003.

4) 田波岳彦, 平田顕啓, 杉田正俊, 齊藤辰哉: 定点観測デー夕 を用いた集中豪雨における名古屋市内の交通状況把握，第34 回交通工学研究発表会(CD-ROM), 2014.

5) 洪性俊, 大口敬: 多車線高速道路における統合型速度推定モ デル，土木学会論文集D3（土木計画学），Vol.67，No.3， pp.244-260, 2011.

6) 日本下水道協会: 下水道施設計画・設計指金十と解説2009年版 (前編)， 2009 .

7) 藤田素弘, 三田村純: 東海集中豪雨下における自動車帰宅交 通状況と走行経路解析, 土木学会論文集, NO.751/IV-62, pp.127-137, 2004.

8) 気象庁: 雨の強さと降り方 (平成12年8月作成) (平成14年1月 一部改正),

http://www.jma.go.jp/jma/kishou/know/yougo_hp/amehyo.html (2014-09).

9) Kelvin C. P. Wang, Wenting Luo, Joshua Q. Li: Hydroplaning Risk Evaluation of Highway Pavements based on IMU and $1 \mathrm{~mm}$ 3D Texture Data, T\&DI Congress 2014, pp. 511-522, 2014.

10) Xin Pei, N. N. Sze, S. C. Wong, Ling Huang, Danya Yao: Disaggregated Crash Prediction Models for Different Crash Types using Joint Probability Model, ICTIS 2013, pp. 1298-1305, 2013.

11) Mei Lam Tam, William H. K. Lam, Biyu Chen, K. S. Chan, S. C. Wong: Using Automatic Vehicle Identification Data for Investigation of Rain Effects on Vehicular Travel Speeds and Travel Choice Behaviour, Traffic and Transportation Studies Congress, pp. 944-955, 2008.

12) D. Atlas, R. C. Srivastava, R. S. Sekhon: Doppler Radar Characteristics of Precipitation at Vertical Incidence, Reviews of Geophysics And Space Physics, Vol.11, Issue 1, pp.1-35, 1973.

13) 警察庁: 交通規制基淮, 平成23年2月4日付讨警察庁丙規発 第3号 警察庁丙交企発第10号.

14）小倉義光: メソ気象の基礎理論, 東京大学出版, 1997.

(2014. 9. 30受付) 